DOI: 10.46340/ephd.2021.7.3.7

\author{
Igor Bigun \\ ORCID ID: https://orcid.org/0000-0002-0351-3894
}

T. G. Shevchenko National University of "Chernigiv Collegium", Kyiv, Ukraine

\title{
BETWEEN THE BUG AND THE HUCZWA: THE VOLHYNIA UPA DETACHMENT IN THE WAR WITH POLISH RESISTANCE IN CHELM LAND (MAY-JULY, 1944)
}

The Ukrainian studies of the Polish-Ukrainian confrontation in Kholmshchyna (Chełm Land) in spring and summer 1944 are usually concentrated either on local civilian casualties of this struggle or just on the Ukrainian Insurgent Army (UPA) units from its Military District (MD) "Bug" of the UPA-West grouping which operated in this land. But it was the distinctive trait of combats between Ukrainian and Polish nationalistic and anti-Nazi Resistance on the "Chełm Front" that not only did units from Galicia participate but also guerillas from the Nazi-occupied Volhynia where UPA-North had operated as well as from other parts of Western Ukraine. It was the Ivan Bogun Detachment that arrived at Kholmshchyna from MD "Turiv" which covered Volhynia Oblast of Soviet Ukraine and some adjacent areas of Belarusian Brest Oblast. The subject of this article embraces the reasons for this unit's raid from Volhynia Oblast to Lublin Voivodeship of the occupied Polish Republic; its structure; its place in fights with Polish partisans, and the course of the unit's raid back to Volhynia.

A thorough examination of the topic would allow enriching the general comprehension of the course of the conflict between the Ukrainian and the Polish liberation movements and the grade of its intensity behind the German lines. The case of the Bogun Detachment would also allow seeing the war situation of the last months of the German occupation of Volhynia and Kholmshchyna. In spring and summer 1944 the German battle-front area was full of various partisan forces: Soviet, Ukrainian, and Polish, which were hotline to one another. Depending on circumstances the Nazis tried either eradicate them or neutralize them via negotiations. As for the Bogun UPA Detachment, it had to experience both options.

Keywords: Ukrainian Insurgent Army, UPA, Kholmshchyna, Chełm Land, Polish-Ukrainian Confrontation, Armija Krajowa, Home Army, Bataliony Chlopskie, Ivan Bogun Detachment, "Turiv" Group, Hrubieszów County.

The Soviet-German frontline in April, 1944 halted within Volhynia Oblast of Ukraine, dividing it in two. Troops of the Red Army $1^{\text {st }}$ Ukrainian and Byelorussian Fronts entrenched along the line KaminKashyrsky-Kovel-Lokachi-Kremenets on its eastern side, when the $4^{\text {th }}$ Panzer Army of the German Wehrmacht Army Group "North Ukraine" stood against them on the west.

The majority of the local Ukrainian Insurgent Army units overcame front and found themselves on its Soviet side. On the German side, although, still stayed two detachments of the "Turiv" Group: one led by Khorunzhy (Lieutenant) Ivan Klymchak-"Lysy" (alias "Pavliuk") in Golovne and Shatsk raions ${ }^{1}$ and another, the Ivan Bogun Detachment, which stationed in Verba Raion, to the north-east of the city of Volodymyr-Volynsky ${ }^{2}$. The stalemate at the frontline continued until July 13, so they did not have any opportunity to cross it ${ }^{3}$.

\footnotetext{
${ }^{1}$ Administrative and territorial division of the Ukrainian lands is given according to that of the Ukrainian SSR in 1940, if other is not mentioned. As for the Polish terrain, I use modern division. The Ukrainian towns and villages' spelling is based on rules of Ukrainian to English transliteration (except for the certainly Polish settlements). Those nowadays located within Poland are spelled in the Polish manner.

${ }^{2}$ Вовк, О. (упоряд.) (2006). Літопис УПА. Нова серія. Волинь, Полісся і Поділля: УПА та запілля 1944-1946.

Документи і матеріали. Київ; Торонто, 8, 1210.

${ }^{3}$ Ibid, 1209.
} 
The Ivan Bogun Detachment consisted of three companies with full strength of 500 soldiers and stationed in the vicinity of Gniyne and Dominopol villages and Boża Wola colony ${ }^{1}$. In April, the detachment was joined by four more companies which straggled from Khvastiv Detachment ${ }^{2}$. That is how the numerical strength of the Bogun Detachment increased, according to various sources, to 600-720 men ${ }^{3}$. As for April, 22, the unit was armed with one $45 \mathrm{~mm}$ cannon, 5 heavy machine-guns, 40 light machine-guns and 5 mortars ${ }^{4}$.

Poruchnyk (Senior Lieutenant) Oleksa Gromadiuk-“Ostrizky" ("Golobenko") had been in charge of the detachment since early March, 1944. Senior Bulavny (Master-Sergeant) "Buria" (N. N.) had been the unit's Chief of Staff since April, 1944. Desiatnyk (Junior Sergeant) Yuriy Moyak-"Nechypir" was the Deputy Commander (he was replaced in July, 1944 by Poruchnyk Ivan Velychko-"Yarema")5. Although O. Gromadiuk's formation was officially called a detachment, it consisted not of battalions, but of independent companies. So in 1944 sources the detachment is often named "Golobenko" (or "Ostrizky") Battalion.

The war situation in the region in the course of March and April, 1944 was becoming more and more tense. The Battle of Kovel went on at the Soviet-German front, and Soviet partisan detachments broke from time to time to the German rear.

In this regard, the Wehrmacht's $4^{\text {th }}$ Panzer Army command tried to clear their rear. In front of charge of the German troops the Bogun detachment had to leave Gniyne and march to Biskupicze-Ruskie (now Nekhvoroshcha), Volodymyr-Volynsky Raion, and its neighbouring villages ${ }^{6}$. The German side, then, sought for cooperation with the UPA, according to Panas Matviychuk-"Vitaliy" ("Krylach"), the Military District "Turiv" Rear Commandant; so they constantly delegated their representatives to the detachment. But they received the only response from the guerillas: to address the Organization of Ukrainian Nationalists Leader Stepan Bandera (who was then detained in the Sachsenhausen concentration camp) because the UPA "obeys only his orders"?.

On May 5 the German military delivered to the staff of the Bogun Detachment an ultimatum: either to give consent for cooperation or relocate to Ustylug Raion. Otherwise, the Nazis threatened to crush insurgents ${ }^{8}$.

Instructor Danylo Shumuk from MD "Turiv" Socio-Political Department, present at the staff, recorded an episode of meeting between 'Ostrizky' and German officers: "Battalion commander 'Ostrizky' came in suddenly [...] He stood at attention in front of 'Mitla' [Oleksiy Prysiazhniuk, Security Service Centre Chief at the UPA-North Staff - I. B.] and reported:

"- Germans arrived on two tanks to negotiate. What are we going to do, talk to them or not?"- asked Ostrizky.

- They didn't want to talk to us in 1941, and now we aren't going to talk to them either. They are politically dead", -replied Mitla.

\footnotetext{
1 Звіт з переходу і дій бойових частин УПА в большевицькому запіллі, групи “Турів”, “Завихост” (від червня 1944 до січня 1945). Архів Центру досліджень визвольного руху. Ф. 9. Т. З0. Арк. 1. <http://avr.org.ua/index.php/viewDoc/1078/> (2021, August, 12); Галузевий державний архів Служби безпеки України (ГДА СБУ). Ф. 6. Спр. 75893фn (архівно-слідча справа Шаї Давидовича Варма), арк. 11зв

${ }^{2}$ Архів Внутрішніх військ НКВС. Ф. 488, On. 1c, Од. 3б. 28, Арк. 307, 3113в; Архів Управління Служби безпеки України (АУСБУ) у Волинській обл. Спр. 12375 (архівно-слідча справа Мояка Юрія Петровича), Арк. 12; Cnp. 8566фn (архівно-слідча справа Дидюка Петра Григоровича), Арк. 9зв; АУСБУ у Рівненській обл. Спр. 76047фn (архівно-слідча справа Гаскевича Володимира Івановича та ін.), Арк. 603в, 63, 67; ГДА СБУ. Ф. 6. Спр. 75893-фn (архівно-слідча справа Шаї Давидовича Варма), Арк. 15зв; Мороз, В. (упоряд.) (2009). Літопис УПА. Воєнна округа Буг. Документи і матеріали 1943-1952. Київ; Торонто: Нова серія, 12, 1 570, 572, 590; Ibid, 132, 431; Шумук, Д. (1983). Пережите і передумане. Спогади й роздуми украӥнського дисидента-політв'язня з років блукань і боротьби під трьома окупаціями України (1921-1981). Детройт: Українські вісті, 173.

${ }_{3}^{3}$ АУСБУ у Рівненській обл., Спр. 76047фn. (архівно-слідча справа Гаскевича Володимира Івановича та ін.). Арк. 67; ГДА СБУ. Ф. 6. Спр. 75893-фn (архівно-слідча справа Варма Шаї Давидовича). Арк. 28; Ковальчук, В., Марчук, І. (упоряд) (2010). Літопис УПА. УПА і запілля на ПЗУЗ 1943-1945. Нові документи. Київ; Торонто: Нова серія, 14, 71-79.

${ }^{4}$ Кентій, А., Лозицький, В., Павленко, І. (упоряд.) (2002). Літопис УПА. Боротьба проти УПА $i$ націоналістичного підпілля: інформачійні документи ЦК КП(б)У, обкомів партї̈, НКВС-МВС, МДБ-КДБ 1943-1959. Книга перша: 1943-1945. Київ; Торонто: Нова серія, 4, 1, 239.

${ }^{5}$ АУСБУ у Волинській обл. Спр. 12375 (архівно-слідча справа Мояка Юрія Петровича). Арк. $113 \mathrm{~s}, 38$.

${ }^{6}$ Вовк, О. (упоряд) (2006). Літопис УПА. УПА і запілля на ПЗУЗ 1943-1945. Нові документи. Київ; Торонто: Нова серія, 8, 653.

${ }^{7}$ Ibid.

${ }^{8}$ Ibid.
} 
Ostrizky formed up once again, knocked his heels, and left"1.

The detachment command decided to move to the area of Lukovychi, Lysiv and Bermeshiv villages, Lokachi Raion, dislodging the Soviet partisan formations' rear guards, whose main forces meanwhile fought with Germans ${ }^{2}$ in the Zavydiv Forest ${ }^{3}$. At 17.00 the Bogun Detachment left Biskupicze Ruske which was immediately occupied by the German motorized units. The red partisans stayed for a while in the villages of Kolona, Rykovychi, Gorokhivka, Stary Zagoriv, Lokachi Raion, from where they departed for Galicia through the Zavydiv Forest ${ }^{4}$. The Germans continued to impose negotiations further, so in the night from 7 to 8 of May, 1944 the detachment relocated to the area of Oryshchi, Zhashkovychi and Volytsia villages in Lokachi Raion 5 .

On May 9, 1944 the next meeting between O. Gromadiuk-“Ostrizky" and the Germans took place in Zhashkovychi. The occupiers proposed taking the guerilla leader to Volodymyr-Volynsky for the purpose of coordinating anti-Soviet struggle. Instructor Danylo Shumuk of the MD "Turiv" Socio-Political Department might had witnessed this very conversation: "One day two cars with Germans arrived at Zhashkovychi to the yard of priest Vasyl Mysechko, and they entered his house. Krylach and I were inside. Germans addressed Krylach and naming him commander Ostrizky declared: "Tomorrow the $4^{\text {th }}$ Panzer Army will come to these lands. They will eradicate all armed groups on its way. We would like to propose you to retreat over Volodymyr under Liuboml. They won't march that way". Krylach thanked, and they went out"6.

But as the negotiations went on, the German units began to surround the detachment, moving up forces to the villages of Buzhkovychi, Stary Zagoriv, Kolona, Topylyshche, Stary Porytsk, Liakhiv (now Starosillia), Janiewicze, Markostav, Chesny Khrest and Silets. The Bogun Detachment Staff gave Germans a guide who had to direct them to a non-existent "competent commander" around Volodymyr-Volynsky to gain some time ${ }^{7}$. "After Germans had gone, Krylach called up Ostrizky, Kuzmenko ${ }^{8}$ and all battalion staff to discuss that situation. They decided to lead the battalion out to Kholmshchyna and in the evening we all went in the direction to the Korytnytsia village almost close to the battlefront," recalled Shumuk".

The detachment was divided into three groups, as P. Matviychuk-"Vitaliy" reported on May, 22 1944, one of which (240-280 men) "Golobenko" led to Galicia, and others had to disperse over the south of Volhynia Oblast ${ }^{10}$.

\footnotetext{
${ }^{1}$ Шумук, Д. (1983). Пережите і передумане : Спогади й роздуми украӥнського дисидента-політв'язня з років блукань і боротьби під трьома окупачіями України (1921-1981). Детройт: Українські вісті, 167.

${ }^{2}$ During April 27-May 10, 1944 lasted the German operation against Budyonny (I. Artiukhov) and RKKA 24 $4^{\text {th }}$

Anniversary (D. Chizhov) partisan formations in the vicinity of Zavydiv and Derechyn villages. It climaxed in combat of Zavydiv on $3^{\text {rd }}$ of May in which the Germans used a motorized infantry battalion and 50 armoured units. (Лозицький В. та ін. (2001). Україна партизанська, 1941-1945. Партизанські формування та органи керівництва ними: науково-довідкове видання. Київ: Парламентське видавництво, 130, 132-133).

${ }^{3}$ АУСБУ у Волинській обл. Спр. 8566фn (архівно-слідча справа Дидюка Петра Григоровича). Арк. 9зв; Вовк, О. (упоряд) (2006). Літопис УПА. УПА і запілля на ПЗУЗ 1943-1945. Нові документи. Київ; Торонто: Нова серія, 8, 654 .

${ }^{4}$ On getting out of the circle in the Zavydiv Forest Artiukhov and Chizhov formations on May 9-10 reached a forest to the east of Kamyanka-Strumylova town in Lviv Oblast where they also had to wage combats either with Germans or with the UPA. (Лозицький В. та ін. (2001). Україна партизанська, 1941-1945. Партизанські формування та органи керівництва ними: науково-довідкове видання. Київ: Парламентське видавництво, 130, 133). ${ }_{5}^{5}$ Вовк, О. (упоряд) (2006). Літопис УПА. УПА і запілля на ПЗУЗ 1943-1945. Нові документи. Київ; Торонто: Нова серія, 8, 654 .

${ }^{6}$ Шумук Д. (1983). Пережите і передумане : Спогади й роздуми украӥнського дисидента-політв'язня з років блукань і боротьби під трьома окупачіями України (1921-1981). Детройт: Українські вісті, 168.

${ }^{7}$ АУСБУ у Волинській обл. Спр. 21435 (архівно-слідча справа Гайдука Дмитра Уляновича та Шевчука Миколи Ананійовича). Арк. 26; Вовк, О. (упоряд) (2006). Літопис УПА. УПА і запілля на ПЗУЗ 1943-1945. Нові документи. Київ; Торонто: Нова серія, 8, 654.

${ }^{8}$ This might have been Ustym Kuzmenko-"Yaroslav", Propaganda (Socio-Political) Department Executive Officer of the Military Superraion "Step" in "Turiv" Group since April 1944 p. (Антонюк, Я. (2014). Украӥнський визвольний рух у постатях керівників. Волинська і Брестська області (1930-1955). Торонто; Львів: Літопис УПА, 385).

${ }^{9}$ Шумук, Д. (1983). Пережите і передумане : Спогади й роздуми українського дисидента-політв'язня з років блукань і боротьби під трьома окупачіями України (1921-1981). Детройт: Українські вісті, 168.

${ }^{10}$ Вовк, О. (упоряд) (2006). Літопис УПА. УПА і запілля на ПЗУЗ 1943-1945. Нові документи. Київ; Торонто: Нова серія, 8, 654-655.
} 
On May 10, 1944 the German units advanced on the villages where the Bogun Detachment units had stationed, but they did not catch anyone. Turning furious they arrested some tens of civilians ${ }^{1}$.

Thus, in the middle of May, 1944 six companies followed O. Gromadiuk for the Chełm Land. These were units of: Pavlo Mykytiuk-"Nerozlychny" (around 40-50 insurgents), Andriy Khil-“Khoma" (40-50), Khorunzhy Dmytro Koreichuk-"Tkach", Ivan Kysil-“Igor", Khorunzhy Vasyl Pavloniuk-"Uzbek" (about 50), and Khorunzhy "Orel" . The rest of men from Bogun Detachment stayed conspiratorially in Volhynia to allow the frontline to pass. Two months later "Golobenko" called these men under the guidance of his deputy Y. Moyak back to the detachment.

After crossing the Bug in the vicinity of Sokal, Lviv Oblast, the Bogun Detachment commander let his subordinates recreate a little. The unit stopped at first in the villages of Sulimów and Hulche (now Hrubieszów County, Lublin Voivodeship in Poland), and then relocated to Korczmin (now Tomaszow Lubelski County), Ugniv (now belongs to Sokal Raion of Lviv Oblast, Ukraine), Laszczów and Tyszowce (Hrubieszów County $)^{3}$. But "Boguners" did not have occasion to rest long.

Active phase of confrontation between Polish Home Army (AK) and Bataliony Chłopskie (BCh) of "Zamość" Inspectorate ("Hrubieszow" and "Tomaszów Lubielski" districts) and UPA units from MD "Bug" of the UPA-West was in full swing. Both sides strove for allotting control over terrain to them, due to what, except pure military casualties, villages were on fire and civil population suffered. A true front over $100 \mathrm{~km}$ long emerged in Kholmshchyna where Poruchnyk Stepan Novytsky-"Spets" (alias "Vadym"), the UPA-West Staff Inspector, was in charge of the Ukrainian forces (15 units, particularly 8 from MD "Bug", 1 from MD "Lysonia", and 1 from UPA-South), and Wilhelm Szczepankiewicz-"Drugak"-those of the Polish (3 AK battalions, $1 \mathrm{BCh}$ Battalion, $20 \mathrm{AK}$ and $4 \mathrm{BCh}$ companies) ${ }^{4}$. Appearance of the Volhynia detachment changed balance in this struggle of favour of the UPA.

The Bogun Detachment had already track record in struggling with Polish Resistance. During 1943, its companies participated in the Polish-Ukrainian ethnic confrontation in Volhynia fighting with Polish Underground placówkas ("outposts"), often German-backed. And a number of Polish villages where these placówkas actually or allegedly stationed were burnt to ashes, and their villagers killed. In February 1944, the Ukrainian villages in the Svynaryn Forest, where the Bogun Detachment's base was, were massacred by the AK 27 Volhynian Division.

On May 19, 1944, another offencive of the Ukrainian forces was set in. Five companies from MD "Bug" together with two ones from "Ostrizky" battalion (over 900 fighters in total) generally led by Ivan Kapalo-"Brodiaga" struck the Home Army base in Nabróz village. Galicians approached from one flank, and Volhynians from another. $2 \mathrm{~km}$ before the village "Nerozluchny" and "Tkach" companies encountered 80 Polish partisans but made them retreat after an hour of fight with 10 men killed $^{5}$.

\footnotetext{
${ }^{1}$ Вовк, О. (упоряд) (2006). Літопис УПА. УПА і запілля на ПЗУЗ 1943-1945. Нові документи. Київ; Торонто: Нова серія, 8, 655 .

${ }^{2}$ Архів Внутрішніх військ НКВС. Ф. 488. On. 1c. Од. 3б. 28. Арк. 307, 311зв; АУСБУ у Волинській обл. Спр. 12375 (архівно-слідча справа Мояка Юрія Петровича). Арк. 12; Ibid. Спр. 22116 (архівно-слідча справа Романюка Олексія Андрійовича та Горбачевського Петра Васильовича). Арк. 43зв, 45зв, 98-99; АУСБУ у Рівненській обл. Спр. 76047фn (архівно-слідча справа Гаскевича Володимира Івановича та ін.). Арк. 60зв, 63, 67; ГДА СБУ. Ф. 6. Спр. 75893-фn (архівно-слідча справа Варма Шаї Давидовича). Арк. 15зв; Ковальчук, В., Марчук, І. (упоряд) (2010). Літопис УПА. УПА і запілля на ПЗУЗ 1943-1945. Нові документи. Київ; Торонто: Нова серія, 8, 12, 570, 572, 590; Ibid, 13, 431; Шумук, Д. (1983). Пережите і передумане : Спогади й роздуми українського дисидента-політв'язня з років блукань і боротьби під трьома окупаціями України (1921-1981). Детройт: Українські вісті, 173.

${ }^{3}$ АУСБУ у Рівненській обл. Спр. $76047 \not n$. (архівно-слідча справа Гаскевича Володимира Івановича та ін.) Арк. 18зв; ГДА СБУ. Ф. 5. Спр. 67432 (архівно-слідча справа Стельмашука Арсенія Трифоновича). Арк. 17, 45; Гордієнко, М (1959). 3 волинських і поліських рейдів УПА (із дій УПА-Північ, 1943-44). Торонто: накладом Товариств колишніх Вояків УПА в Канаді і США, 155; Ковальчук, В., Марчук, І. (упоряд) (2010). Літопис УПА. УПА і запілля на ПЗУЗ 1943-1945. Нові документи. Київ; Торонто: Нова серія, 13, 430; Ibid, 15, 150. ${ }^{4}$ Мотика, Г. (2013). Від Волинської різанини до акиії “Вісла”. Польсько-український конфлікт $1943-1947$ рр. Київ: Дух і літера, 186.

${ }^{5}$ АУСБУ у Волинській обл. Спр. 5891 фn (архівно-слідча справа Панчука Івана Германовича та ін.) Арк. 16-17; ГДА СБУ. Ф. 5. Спр. 67432 (архівно-слідча справа Стельмащука Арсенія Трифоновича). Арк. 51; В’ятрович, В. (2012). Друга польсько-українська війна 1942-1947. 2-ге доповнене видання. Київ: Видавничий дім “Києво-Могилянська академія", 197; Ковальчук, В., Марчук, І. (упоряд) (2010). Літопис УПА. УПА $і$ запілля на ПЗУЗ 1943-1945. Нові документи. Київ; Торонто: Нова серія, 12, 304; Літопис УПА. Ibid, 13, 430-431.
} 
At the other flank, the Polish soldiers resisted hard for four hours, but the Ukrainian insurgents were finally victorious. Some part of the Polish units fought their way in the direction of Tyszowce, and anotherin Stara Wies. "Perekotypole" Company's outpost which had stationed in Stara Wies retreated in front of the Polish advance, but the "Vovky" company came to their assistance and defeated the AK group ${ }^{1}$.

A Nazi gendarmerie unit, which arrived from Tyszowce by four lorries, also intervened in the fight. On having a short skirmish with "Tkach" company the invaders fled leaving several corpses. The guerillas lost two killed and five wounded ("Tkach" himself among them). Meanwhile a German plane came flying and injured four policemen, who were marching to reinforce the Germans, by friendly fire ${ }^{2}$.

In total, Polish bases in Nabróz, Kryszyn, Tuczapy, Mołożów, Lipowce and Marysin colony were burnt as a result of operation. The AK casualties comprised 46 dead (Polish sources argued that 30 among them were civilians) and several POWs. Polish units under general command of Reserve Porucznik Zenon Jachymek-"Wiktor" were made to fall back over the Huczwa river. The UPA units had 2 killed by German fire and 8 injured (including 5 in the fight with Germans). Their trophies were: a machine-gun, over ten rifles and cattle ${ }^{3}$.

But the $\mathrm{AK}$ and $\mathrm{BCh}$ leadership did not submit to their defeat and prepared a counterattack. On the night from 1 to 2 June, 1944 AK, BCh and State Security Corps troops (1200 soldiers divided into 8 striking forces) led by Z. Jachymek-"Wiktor" who was appointed the new commander of the Eastern Sector of the Anti-Ukrainian Defence in "Tomaszów Lubielski" District rushed to advance at the $40 \mathrm{~km}$ front section. Main lines of operation were: 1) on the villages of Hubinek, Dyniska, Ulhówek, Żerniki, Rzeczyca; 2) on Posadów, Steniatyn and Rzeplin; 3) on Dąbrowa and Stara Wies, in the vicinity of which the UPA bands (800-900 fighters) were located ${ }^{4}$. The main goal of the operation was to destroy Ulhówek and Rzeczyca where the strongest UPA forces on the south west of Lublin Voivodeship concentrated ${ }^{5}$.

The force No. 3 led by Tadeusz Nedzialkowski-“Tomasz" approached Ulhówek from the side of Żerniki and Rzeczyca. Polish partisans had burnt down Żerniki (33 civilians dead), Ratyczow (32 dead), Zimno (1 person), and Szlatyn ${ }^{6}$. But Ulhówek charge broke down, and insurgents forced the Poles $12 \mathrm{~km}$ back $^{7}$. In addition, the force No. 2 of Anrzej Dżygalo-"Korczak" which had to attack Posadów-Ulhówek from the north, failed to assist because they got stuck in fights at avenues of approach and managed to reach only woods around Posadów and Zapust near Rzeplin ${ }^{8}$.

Not long before the defined time of attack on Ulhówek, "Korczak"s men set on fire and looted Steniatyn Colony (25 Ukrainians died) and Posadów Village (10 perished); that got Ukrainian defenders to learn that the offence was going on from that direction'. When the force No. 2 stationed in the Posadów Forest, its outposts in Rzeplin were charged from Przewodów side by the UPA "Tygry" Company, causing significant casualties in killed, injured, and captured men ${ }^{10}$.

\footnotetext{
${ }^{1}$ АУСБУ у Волинській обл. Спр. 5891фn (архівно-слідча справа Панчука Івана Германовича та ін.). Арк. 16-17; В'ятрович, В. (2012). Друга польсько-украӥнська війна 1942-1947. Київ: Видавничий дім "Києво-Могилянська академія", 197; Ковальчук, В., Марчук, І. (упоряд) (2010). Літопис УПА. УПА і запілля на ПЗУЗ 1943-1945. Нові документи. Київ; Торонто: Нова серія, 12, 304; Ibid, 13, 430-431.

${ }^{2}$ Ibid.

${ }^{3}$ В’ятрович, В. (2012). Друга польсько-українська війна 1942-1947. Київ: Видавничий дім "Києво-Могилянська академія", 197; ГДА СБУ. Ф. 5. Спр. 67432 (архівно-слідча справа Стельмамука Арсенія Трифоновича). Арк. 45; Ковальчук, В., Марчук, І. (упоряд) (2010). Літопис УПА. УПА і запілля на ПЗУЗ 1943-1945. Нові документи. Київ; Торонто: Нова серія, 13, 430-431.

${ }_{4}^{4}$ В’ятрович, В. (2012). Друга польсько-украӥнська війна 1942-1947. Київ: Видавничий дім "Києво-Могилянська академія", 197; Bohunow, S., Winiarczyk-Kossakowska, M., Gajowniczek, Z. ta inny (red.) (2005). Polska i Ukraina w Latach Trzydziestych-Czterdziestych XX Wieku. Nieznane Dokumenty z Archiwów Stużb Specjalnych. Polacy i Ukraińcy Pomiędzy Dwoma Systemami Totalitarnymi 1942-1945. Warszawa; Kijów, 4, 2, 1404; Zająnczkowski, M. (2015). Ukrainskie podziemie na Lubelszyznie w okresie okupacji niemieckiej 1939-1944. Lublin-Warzawa: ISP PAN, 330. ${ }^{5}$ Zająnczkowski, M. (2015). Ukrainskie podziemie na Lubelszyznie w okresie okupacji niemieckiej 1939-1944. Lublin-Warzawa: ISP PAN, 366.

${ }^{6}$ Ibid, 369.

${ }^{7}$ Ковальчук, В., Марчук, І. (упоряд) (2010). Літопис УПА. УПА і запілля на ПЗУЗ 1943-1945. Нові документи. Київ; Торонто: Нова серія, 12, 305, 421.

${ }^{8}$ Zająnczkowski, M. (2015). Ukrainskie podziemie na Lubelszyznie w okresie okupacji niemieckiej 1939-1944. Lublin-Warzawa: ISP PAN, 368.

${ }^{9}$ Ibid.

${ }^{10}$ Ibid; Ковальчук, В., Марчук, I. (упоряд) (2010). Літопис УПА. УПА і запілля на ПЗУЗ 1943-1945. Нові документи. Київ; Торонто: Нова серія, 12, 305.
} 
The biggest fights during the whole day of June 2 were on the Posadów-Rzeczica sector. Rzeczica was to no effect attacked by striking force No. 4 of Franciszek Bednarski-"Reneta" (around 600 guerillas). Being disrupted, the Poles stuck from the northern, not southern, side of the village, which was more fortified, and did that with a delay. The Mykhailo Khvalibota-"Lys" Company ("Perebyinis") and local Ukrainian selfdefence held all-round defence. Even when "Wiktor" arrived himself to take the direct command, and most of units of "Tomasz" did, this would not turn the tide. Ultimately, "Wiktor" ordered "Reneta"s soldiers to retreat, and sent F. Bednarski as a reinforcement for "Korczak" near Ulhówek. But UPA troops seized the initiavite and counterattacked, offering the Poles new battles, until 17.00.

"Reneta"s defeat near Rzeczica and "Korczak"s inactivity near Ulhówek determined finally the fail of the whole operation. That fact could not be changed by the fulfillment of rest 5 striking forces' entrusted tasks and successes on the secondary directions of the Polish offensive," concludes Mariusz Zajączkowski, a Polish historian ${ }^{1}$.

In the course of retreat, the AK forces burned down the Ukrainian villages: Magdalenka Farm, Hubinek, Podlodów, and Peniany, individual households in Dynyska and Rzeczica ${ }^{2}$.

Only at 10.30 did the bulk of "Korczak" forces engage fights in the vicinity of Rokitno, Przewodów, and Leski. But the UPA units repulsed this attack close to Ulhówek, and after "Korczak" drew his units to the Posadów forest ${ }^{3}$.

The Bogun Detachment held positions near the Lachowce village in this operation. "Ostrizky"s riflemen engaged 200-300 AK soldiers who after burning Posadów down advanced in the direction of Ratków and Lachowce (these were likely "Korczak" group units). The Poles tried to hold in the Ratków woods, but "Ostrizky" surrounded it and ordered his submachine-gunners to centre fire on it to press the Poles on the Galician companies' ambush. About 40 partisans were killed by crossfire, the rest rapidly retreated in panic ${ }^{4}$.

The same afternoon, according to M. Zajączkowski, "Ostrizky" Battalion came to assistance to "Vovky" Company of M. Lukasevych-"Yagoda" which had been repulsing attacks by grouping No. 1 of the Polish forces under Marian Pilaski-"Grom" command in the area of Stara Wies and Dąbrowa since late night. The Polish battalion advanced from the woods near Tyszowce to Lipowce, Mołożów and woods near Stara Wies with the task to cover main striking forces' activities from the north. But "Yagoda"s Company occupying Dąbrowa turned out to be a complete surprise for them. The desperate resistance of "Vovky" lasted for about 18 hours, and Poles, in the end, faild to seize Dabrowa. When twighlight came, "Grom"s force pressed by the UPA units retreated to Lipowce Forest. At this sector of front, casualties of Ukrainians made up 6-8 killed and 4 injured from "Yagoda"s Company; Polish partisans lost 13 men, and there also were 16 people (presumably civilians) killed by AK men in Lipowce ${ }^{5}$.

According to Ukrainian and Polish sources, the Polish detachments lost in night battles of June 2, 1944, in general, 71 partisan killed, and 100 more injured $^{6}$. Ukrainian insurgents' casualties comprised 6-8 men, but civil population suffered more - about 120 people perished in Steniatyn colony, Posadów, Ratyczów, Żerniki, Zimno, Lipowce ${ }^{7}$.

"In the end, the "Polish-Ukrainian front" stabilized on the Uhnów-Żerniki-Steniatyn-Nabróz line, then along the Huczwa up to Koniuchy, and futher through Bereść village to Grabowiec. Such situation was preserved in this terrain until the Red Army came," historian Grzegorz Motyka summarized ${ }^{8}$.

\footnotetext{
${ }^{1}$ Zająnczkowski, M. (2015). Ukrainskie podziemie na Lubelszyznie w okresie okupacji niemieckiej 1939-1944. Lublin-Warzawa: ISP PAN, 371.

${ }^{2}$ Ibid, 371.

${ }^{3}$ Ibid, 370.

${ }^{4}$ ГДА СБУ. Ф. 5. Спр. 67432 (архівно-слідча справа Стельмашука Арсенія Трифоновича). Арк. 51; Ковальчук, В., Марчук, І. (упоряд) (2010). Літопис УПА. УПА і запілля на ПЗУЗ 1943-1945. Нові документи. Київ; Торонто: Нова серія, 12, 305, 421; Шумук, Д. (1983). Пережите і передумане: Спогади й роздуми украӥнського дисидента-політв'язня з років блукань і боротьби під трьома окупаџіями України (1921-1981). Детройт: Українські вісті, 186.

${ }^{5}$ Winiarczyk-Kossakowska, M., Gajowniczek, Z. ta inny (red.) (2005). Polska i Ukraina w Latach TrzydziestychCzterdziestych XX Wieku. Nieznane Dokumenty z Archiwów Służb Specjalnych. Polacy i Ukraińcy Pomiędzy Dwoma Systemami Totalitarnymi 1942-1945. Warszawa; Kijów, 4, 1404; Zająnczkowski, M. (2015). Ukrainskie podziemie na Lubelszyznie w okresie okupacji niemieckiej 1939-1944. Lublin-Warzawa: ISP PAN, 367.

${ }^{6}$ Мотика, Г. (2013). Від Волинської різанини до акиії “Вісла”. Польсько-український конфлікт $1943-1947$ рр. Київ: Дух і літера, 186.

${ }^{7}$ Ковальчук, В., Марчук, І. (упоряд) (2010). Літопис УПА. УПА і запілля на ПЗУЗ 1943-1945. Нові документи. Київ; Торонто: Нова серія, 12, 305; Zająnczkowski, M. (2015). Ukrainskie podziemie na Lubelszyznie w okresie okupacji niemieckiej 1939-1944. Lublin-Warzawa: ISP PAN, 372.

${ }^{8}$ Ibid.
} 
Overall, "Ostrizky" companies in Chełm Land took part in four combats with Polish partisans and prevailed $^{1}$. The rest of its Chełm period the Bogun Detachment raided along the Western Bug at 14-16 km distance from it and $30-35 \mathrm{~km}$ from $\mathrm{Chelm}^{2}$.

When quartering in one of the villages "Ostrizky" battalion was visited by the UPA-North Commander Dmytro Kliachkivsky-"Klym Savur" who also was on the German side of front. By his June 27, 1944 order, he appointed O. Gromadiuk-"Ostrizky" the "Turiv" Group Deputy Commander and the commander of the Group's units on the German side of front. In addition to the Bogun Detachment, I. Klymchak-"Lysy" detachment belonged to them ${ }^{3}$.

Danylo Shumuk recalled one of the episodes of their daily life in Chełm Land in June 1944: "Ostrizky battalion stationed in Korczmin. [...] Our battalion's outpost was located at the edge of the village. Once the outpost detained two armoured cars on that road. German army officers drove them. The outpost did not let them in the village. The Germans declared in ultimatistic manner: "Get lost from here until the next morning. The German Army will march this way, so it will exterminate all armed groups on its way." After that ultimatum Ostrizky ordered his company leaders to take their companies to the woods. He entrusted the command over the whole battalion to "Nerozluchny" and together with his deputies departed somewhere on his service affairs" 4 .

Petro Lykhovsky, the Bogun Detachment magazine keeper ("magaziner"), must have meant one of such cases when he gave testimony during the Soviet NKVD interrogation: "When "Golubenko"s gang was on the territory of Poland, German officers came to "Golubenko" and talked with him about something; but about what did they talk I cannot tell'"5.

Yevgen Tatura-'Omelko', the UPA-North Staff Foreign Communications Division Officer, who stayed with the detachment, also had a conversation with a German representative. The subject of their talk was the transfer of a railway car with ammunition to insurgents. In the evening that day, Mykola Pavlovych, the Deputy Chief of Staff of the "Turiv" Group, accompanied Tatura and the German on their way to Zamość, where they obtained 10 ammo crates designated for 'Lysy' battalion. They transported the ammunition to Włodawa 6 .

But in spite of local agreements with individual German commanders, the general relations between the Bogun Detachment and the Nazis were hostile. On June 19, 1944 a German company attacked insurgents at 18.00 o'clock when the detachment was resting around the village of Sahryń. After three-hour fight the enemy lost four dead and seven wounded and UPA casualties were limited to one injured ${ }^{7}$.

In the middle of July 1944 the battalion, following the instructions of "Klym Savur", marched from Lachowce to the North but, near the village of Grabowiec ${ }^{8}$ it ran into large German

\footnotetext{
1 Звіт $з$ переходу і дій бойових частин УПА в большевицькому запіллі, групи “Турів”, “Завихост” (від червня 1944 до січня 1945). Архів Центру досліджень визвольного руху. Ф. 9. Т. З0. Арк. 1. <http://avr.org.ua/index.php/viewDoc/1078/>. (2021, September, 01).

${ }^{2}$ ГДА СБУ. Ф. 5. Спр. 67432 (архівно-слідча справа Стельмашука Арсенія Трифоновича). Арк. 65; Ibid. Ф. 6. Спр. 75893-фn (архівно-сліча справа Шаї Давидовича Варма). Арк. 12.

${ }^{3}$ Ковальчук, В., Марчук, І. (упоряд) (2010). Літопис УПА. УПА і запілля на ПЗУЗ 1943-1945. Нові документи. Київ; Торонто: Нова серія, 14, 63-64.

${ }^{4}$ Шумук, Д. (1983). Пережите і передумане : Спогади й роздуми украӥнського дисидента-політв'язня з років блукань і боротьби під трьома окупаціями України (1921-1981). Детройт: Українські вісті, 171-169.

${ }^{5}$ Власенко, С., Кокін, С., Лозицький, В. (упоряд.) (2011). Літопис УПА. УПА і запілля на ПЗУЗ 1943-1945.

Нові документи. Боротьба проти УПА і націоналістичного підпілля: протоколи допитів заарештованих радянськими органами державної безпеки керівників ОУН і УПА 1945-1954. Київ; Торонто: 15, $2,142$. ${ }^{6}$ Ibid, 97-98.

${ }^{7}$ Ковальчук, В., Марчук, І. (упоряд) (2010). Літопис УПА. УПА і запілля на ПЗУЗ 1943-1945. Нові документи. Київ; Торонто: Нова серія, 8, 1174.

${ }^{8}$ A Ukrainian emigration historian Lev Shankovsky wrote with no reference that "on June 12 the UPA units (com. Ostrizky) crossed the Huczwa and started advancing in Grabowiec direction ... the whole terrain till the line UchanieOrnatowice-Horeszów-Ruski-Czermno was moped up from the AK units and Polish militias. Several fights with AK units and Germans were initiated by the UPA units which were victorious. This terrain remained in the Ukrainian hands until the passage of frontline in July 1944" (Шанковський, Л. (1953). Історія УПА, 74). Hе was echoed by the Polish researchers Andrzej Leon Sowa (1998) and Mariusz Zająnczkowski (2015). Although, the sources related to the "Ostrizky" Battalion tell us only about Grabowiec combat with Nazis of July 1944, and there is no data about clashes with the Polish Resistance except mentioned above. Shankovsky's argument seems more doubtful given that the distance from Czermno to Uchanie makes $37 \mathrm{~km}$ - too far to cover and mop up during one day. And finally, "Ostrizky" certainly stayed in Sahryń as of $19^{\text {th }}$ of June, on the Huczwa eastern bank, $35 \mathrm{~km}$ far from Uchanie.
} 
forces $^{1}$. After a severe night battle the Bogun Detachment was made to fall back to Dąbrowa, where guerillas waited for two nights and days until the frontline advanced westwards ${ }^{2}$. One of the platoon leaders recalled his impression: "We happened to be caught in the crossfire in a tiny grove: Germans were striking us from one side, and Soviets from another, and we could not get away, should we have dug in. That is how we were beaten."

This was the time when the Red Army conducted the Lvov-Sandomierz offensive. Until July 21, divisions of the $3^{\text {rd }}$ Guards Army reached the line Stara Wies-Kmiczyn-Kulice-Telatyn. The German $4^{\text {th }}$ Panzer Army defended the line Hrubieszów-Werbkowice-Tyszowce-Laszczów ${ }^{4}$. Being between the devil and the deep blue sea but already behind the line of the Soviet troops "Golobenko" battalion in small teams fought their way further in the Soviet rear ${ }^{5}$.

Staff worker Y. Moyak-"Nechypir" also bore testimony about harsh conditions of crossing the frontline: "Golobenko had to agree with Germans on crossing the front but didn't dare to breech. He ordered all the six companies to disperse in small groups and make their way. After that "Uzbek" and "Orel" companies disintegrated completely, and their commanders vanished to an unknown destination" 6 .

Roughly on July 25, 1944 elements of the "Ostrizky" Detachment crossed the river in the vicinity of Litovezh village, Porytsk Raion, Volhynia Oblast, and returned to the territory of, by that time, Soviet Ukraine?

According to "Nechypir", the detachment numbered about 600 riflemen before their break through the frontline, from which only less than 200 gathered at the rendevouz point near Porytsk over the Bug ${ }^{8}$. But other testimonies provide such figures as 320-365 active men'.

After returning to Volhynia, company leaders "Nerozluchny", "Khoma", "Igor", "Kudyar" (alias "Roman"), "Uzbek", and "Orel" were subject to the staff of "Ostrizky" battalion. "Kudyar" might have replaced "Tkach" who got injured in the $19^{\text {th }}$ of May combat and stayed in Galicia for treatment. "Uzbek" and "Orel" companies were not battle-worthy - the majority of their riflemen dispersed in the course of hard breakthrough ${ }^{10}$.

\footnotetext{
1 Звіт з переходу і дій бойових частин УПА в большевицькому запіллі, групи “Турів”, “Завихост” (від червня 1944 до січня 1945). Архів Центру досліджень визвольного руху. Ф. 9. Т. 30. Арк. 1. <http://avr.org.ua/index.php/viewDoc/1078/> (2021, September, 01); ГДА СБУ. Ф. 6. Спр. 75893-фn (архівно-слідча справа Варма Шаї Давидовича). Арк. 12; Гордієнко, М. (1959). 3 волинських і поліських рейдів УПА, 155; Новак, В. (“Крилатий”) (1984). Північно-західня округа “Турів”. Літопис Української Повстанської Армї. Волинь і Полісся. Кн. третя: спомини учасників. Торонто: Літопис УПА, 5, 173.

2 АУСБУ у Рівненській обл. Спр. Р-7683 (архівно-слідча справа Власюка Олександра Івановича та Години Павла Григоровича). Арк. 14зв; ГДА СБУ. Ф. 6. Спр. 75893-фn (архівно-слідча справа Варма Шаї Давидовича). Арк. 12; Гордієнко, М (1959). 3 волинських і поліських рейдів УПА (із дій УПА-Північ, 1943-44). Торонто: накладом Товариств колишніх Вояків УПА в Канаді і США, 134.

${ }^{3}$ Шумук, Д. (1983). Пережите і передумане : Спогади й роздуми украӥнського дисидента-політв'язня з років блукань і боротьби під трьома окупаціями Украӥни (1921-1981). Детройт: Українські вісті, 177.

${ }^{4}$ Карта “Положение войск 3-й гвардейской армии с 18 по 25.07.1944”. Центральный архив

Министерства обороны Российской Федерации. Ф. 312. Оп. 3245. Д. 239. Л. 7. <https://bit.ly/343tTED> (2021, September, 01).

${ }^{5}$ ГДА СБУ. Ф. 5. Спр. 67432 (архівно-слідча справа Стельмащука Арсенія Трифоновича). Арк. 17, 45-46; Гордієнко, М (1959). 3 волинських і поліських рейдів УПА (із дій УПА-Північ, 1943-44). Торонто: накладом Товариств колишніх Вояків УПА в Канаді і США, 155-156; Новак, В. (“Крилатий”) (1984). Північно-західня округа “Турів”. Літопис Української Повстанської Армії. Волинь і Полісся. Кн. третя: спомини учасників. Торонто: Літопис УПА, 134.

${ }^{6}$ АУСБУ у Волинській обл. Спр. 12375 (архівно-слідча справа Мояка Юрія Петровича). Арк. 11зв-12.

${ }^{7}$ Літопис УПА. Нова серія. Т. 8, 1210; Архів Внутрішніх військ НКВС. Ф. 488. Оп. 1с. Од. зб. 28. Арк. 392; ГДА СБУ. Ф. 16. Спр. 544. Арк. 183.

${ }^{8}$ АУСБУ у Волинській обл. Спр. 12375 (архівно-слідча справа Мояка Юрія Петровича). Арк. 12.

${ }^{9}$ Вовк, О. (упоряд) (2006). Літопис УПА. УПА і запілля на ПЗУЗ 1943-1945. Нові документи. Київ; Торонто: Нова серія, 8, 1210; Новак, В. (“Крилатий”) (1984). Північно-західня округа “Турів”. Літопис Украӥнськой Повстанської Армії. Волинь і Полісся. Кн. третя: спомини учасників. Торонто: Літопис УПА, 134. ${ }^{10}$ Архів Внутрішніх військ НКВС. Ф. 488. On. 1c. Од. зб. 31. Арк. 217; ГДА СБУ. Ф. 6. Спр. 75893-фn (архівнослідча справа Варма Шаї Давидовича). Арк. 12; Вовк, О. (упоряд) (2006). Літопис УПА. УПА $і$ запілля на ПЗУЗ 1943-1945. Нові документи. Київ; Торонто: Нова серія, 8, 739; АУСБУ у Волинській обл. Спр. 12375 (архівно-слідча справа Мояка Юрія Петровича). Арк. 33, 34, 43.
} 
At first, the Bogun Detachment stopped on Volhynian land in the village of Ivanychi, Porytsk Raion. Then, avoiding clashes with the Soviet forces the insurgent unit marched to the North-Eastern direction up to the area of Gorno village, Manevychi Raion'.

O. Gromadiuk-"Ostrizky" and his soldiers found themselves in new circumstances which emerged as the Soviet totalitarian regime was back in Volhynia. Since then, their main adversaries were units of the $9^{\text {th }}$ Rifle Division of the NKVD Interior Troops, quartering in settlements within Volhynia Oblast and neighbouring raions of Rivne Oblast. Bogun Detachment waged a number of victorious fights with their elements during August-September, 1944 while looking for connection with UPA higher command ${ }^{2}$.

It can be concluded, that the arrival of the Ivan Bogun UPA Detachment in Chełm Land at the end of spring 1944 became one of the decisive factors which reinforced the positions of the Ukrainian Liberation Movement in this area. The Ukrainian insurgents dominated over the Polish Resistance there until the German occupation of the Chełm Land ended and the Red Army arrived.

\section{References:}

1. Antoniuk, Y. (2014). Ukrainsky Vyzvolny Rukh u Postatiakh Kerivnykiv. Volynska i Brestska Oblasti (1930-1955) [The Ukrainian Liberation Movement Through the Biographies of its Leaders. Volhynia and Brest Oblasts (1930-1955)]. Toronto; Lviv: Litopys UPA. [in Ukrainian].

2. Arkhiv Upravlinnia Sluzhby bezpeky Ukrainy u Volyskiy oblasti [Volhynia Oblast Directorate Archives of the Security Service of Ukraine]. File 12375 (Archival Investigatory File on Yuriy Petrovych Moyak). [in Russian].

3. Arkhiv Upravlinnia Sluzhby bezpeky Ukrainy u Volyskiy oblasti [Volhynia Oblast Directorate Archives of the Security Service of Ukraine]. File 8566fp (Archival Investigatory File on Petro Grygorovych Dydiuk). [in Russian].

4. Arkhiv Upravlinnia Sluzhby bezpeky Ukrainy u Volyskiy oblasti [Volhynia Oblast Directorate Archives of the Security Service of Ukraine]. File 5891fp (Archival Investigatory File on Ivan Germanovych Panchuk, Leon Kuzmych Muzychuk, and Sergiy Sazonovych Pryimak). [in Russian].

5. Arkhiv Upravlinnia Sluzhby bezpeky Ukrainy u Volyskiy oblasti [Volhynia Oblast Directorate Archives of the Security Service of Ukraine]. File 21435 (Archival Investigatory File on Dmytro Ulianovych Gaiduk and Mykola Ananiyovych Shevchuk). [in Russian].

6. Arkhiv Upravlinnia Sluzhby bezpeky Ukrainy u Volyskiy oblasti [Volhynia Oblast Directorate Archives of the Security Service of Ukraine]. File 22116 (Archival Investigatory File on Oleksiy Andriyovych Romaniuk and Petro Vasyliovych Gorbachevsky). [in Russian].

7. Arkhiv Upravlinnia Sluzhby bezpeky Ukrainy v Rivnenskiy oblasti [Rivne Oblast Directorate Archives of the Security Service of Ukraine]. File 76047fp (Archival Investigatory File on Volodymyr Ivanovych Gaskevych et al). [in Russian].

8. Arkhiv Upravlinnia Sluzhby bezpeky Ukrainy v Rivnenskiy oblasti [Rivne Oblast Directorate Archives of the Security Service of Ukraine]. File P-7683 (Archival Investigatory File on Oleksandr Ivanovych Vlasiuk and Pavlo Grygorovych Godyna). [in Russian].

9. Akhiv Vnutrishnikh viysk NKVD [NKVD Interior Troops Archives, microfiche copies are stored in the ACDVR]. Fonds. 488. Inventory (Series). 1c. Items 29, 31. [in Russian].

10. Galuzevy derzhavny arkhiv Sluzhby bezpeky Ukrainy [Security Service of Ukraine Branch State Archives]. Fonds. 5. File 67432 (Archival Investigatory File on Arseniy Tryfonovych Stelmashchuk). [in Russian].

11. Galuzevy derzhavny arkhiv Sluzhby bezpeky Ukrainy [Security Service of Ukraine Branch State Archives]. Fonds. 6. File 75893fp (Archival Investigatory File on Shaya Davidovich Varm). [in Russian].

12. Galuzevy derzhavny arkhiv Sluzhby bezpeky Ukrainy [Security Service of Ukraine Branch State Archives]. Fonds. 16. File 544. [in Russian].

13. Gordiyenko, M., Novak, V. (1959). Z volynskykh i poliskykh raidiv UPA (iz diy UPA-Pivnich, 1943-1944) [Fighting in the Ranks of UPA-North (Memories from UPA in Volynia and Polissya in 1943-1944)]. Toronto: nakladom Tovarystv kolyshnikh Voyakiv UPA v Canadi i SshA. [in Ukrainian].

14. Kentiy, A., Lozytsky, V., Pavlenko, I. (comp.) (2002). Litopys UPA. T. 4. Borotba Proty UPA i Natsionalitychnogo Pidpillia: Informatsiyni Dokumenty CK KP(b)U, Obkomiv Partiyi, NKVS-MVS, MDB-KDB 1943-1959.

\footnotetext{
${ }^{1}$ Гордієнко, М (1959). 3 волинських і поліських рейдів УПА (із дій УПА-Північ, 1943-44). Торонто: накладом Товариств колишніх Вояків УПА в Канаді і США, 156; Звіт з переходу і дій бойових частин УПА в большевицькому запіллі, групи “Турів”, “Завихост” (від червня 1944 до січня 1945). Архів Центру досліджень визвольного руху. Ф. 9. Т. 30. Арк. 1. <http://avr.org.ua/index.php/viewDoc/1078/> (2021, September, 01).

${ }^{2}$ Гордієнко, М (1959). 3 волинських і поліських рейдів УПА (із дій УПА-Північ, 1943-44). Торонто: накладом Товариств колишніх Вояків УПА в Канаді і США, 156, 158, 165; Вовк, О. (упоряд) (2006). Літопис УПА. УПА і запілля на ПЗУЗ 1943-1945. Нові документи. Київ; Торонто: Нова серія, 8, 738-739, 1174-1175, 1209.
} 
Knyga Persha: 1943-1945 [Struggle Against the UPA and Nationalist Underground: Informational Documents of the CP(B)U CC, Oblast Party Commitees, NKVD-MVD, MGB-KGB 1943-1959. Book 1: 1943-1945]. Kyiv; Toronto: Nova Seriya [in Russian].

15. Vovk, O. (comp.) (2006). Litopys UPA. Volyn, Polissia i Podillia: UPA ta Zapillia 1944-1946. Dokumenty $i$ Materialy [Volhynia, Polissia, and Podolia: the UPA and its Rear Line 1944-1946. Documents and Materials]. Kyiv; Toronto: Nova Seriya, 8. [in Ukrainian].

16. Moroz, V. (comp.) (2009). Litopys UPA. Voyenna Okruga “Bug”. Dokumenty i Materialy 1943-1952 [Military District "Bug". Documents and Materials 1943-1952]. Kyiv; Toronto: Nova Seriya, 12, 1. [in Ukrainian].

17. Moroz, V. (comp.) (2009). Litopys UPA. Nova Seriya. T. 13. Voyenna Okruga “Bug”. Dokumenty i Materialy 1943-1952 [Military District “Bug”. Documents and Materials 1943-1952]. Kyiv; Toronto: Nova Seriya, 13. [in Ukrainian].

18. Kovalchuk, V., Marchuk, I. (comp.) (2010). Litopys UPA. UPA i zapillia na PZUZ 1943-1945. Novi dokumenty [The UPA and Rear Line in North-Western Ukrainian Lands 1943-1945 New Documents]. Kyiv; Toronto: Nova Seriya, 14. [in Ukrainian].

19. Vlasenko, S., Kokin, S., Lozytksy, V. (comp.) (2010). Litopys UPA. Nova seriya. Borotba proty povstanskogo rukhu i natsionalistychnogo pidpillia: protokoly dopytiv zaareshtovanykh radianskymy organamy derzhavnoyi bezpeky kerivnykiv OUN i UPA 1945-1954 [The Struggle Against Insurgent Movement and the Nationalist Undergakround: Interrogation Protocols of OUN and UPA Leaders Arrested by the Soviet State Security Organs1945-1954]. Kyiv; Toronto: Nova Seriya, 15, 2. [in Russian].

20. Lozytsky, V. (2001). Ukraina Partyzanska. 1941-1945. Partyzanski Fromuvannia ta Organy Kerivnytstva Nymy: Naukovo-Dovidkove Vydannia [The Partisan Ukraine. 1941-1945. Partisan Formations and Their Command Units: Scholarly and Reference Book]. Kyiv: Parlamentske Vydavnytstvo. [in Ukrainian].

21. Novak, V. ("Krylaty") (1984). Pivnichnozakhidnia okruga “Turiv" [The UPA's North-Western Military Region "Turiv"]. Litopys Ukrainskoyi Povstanskoyi Armiyi. Volyn i Polissia. Nimetska okypatsiya. Spomyny uchasnykiv. [Chronicle of the Ukrainian Insurgent Army. Volyn and Polissya. German occupation. Backs of the participants]. Toronto: Litopys UPA, 5, 3, 96-134. [in Ukrainian].

22. Map " 3 rd Guards Army Troops Disposition from 18 to 25.07.1944". Tsentralny Arkhiv Ministerstva Oborony Rossiyskoy Federatsii [Central Archives of the Russian Federation Ministry of Defense]. Fonds. 312. Inventory. 3245. File. 239. Sheet 7. <https://bit.ly/343tTED>. (2021, September, 01). [in Russian].

23. Motyka, G. (2013). Vid Volynskoyi Rizanyny do Aktsiyi "Visla”. Polsko-Ukrainsky Konflikt $1943-1947$ rr. [From Volhynia Masacre to the Vistula Action. Polish-Ukrainian Conflict 1943-1947]. Kyiv: Dukh i Litera. [in Ukrainian].

24. Winiarczyk-Kossakowska, M., Gajowniczek, Z. and others (ed.) (2005). Polska i Ukraina w Latach TrzydziestychCzterdziestych XX Wieku. Nieznane Dokumenty z Archiwów Stużb Specjalnych. Polacy i Ukraińcy Pomiędzy Dwoma Systemami Totalitarnymi 1942-1945 [Poland and Ukraine in the 1930s and 1940s. Unknown Documents from the Archives of Special Services. Poles and Ukrainians Between Two Totalitarian Systems 1942-1945]. Warszawa; Kijów, 4. [in Polish].

25. Shankovsky, L. (1953). Istoriya UPA [The history of the UPA]. Winnipeg. [in Ukrainian].

26. Shumuk, D. (1983). Perezhyte i Peredumane. Spogady i Rozdumy Ukrainskogo Dysydenta-Politvyaznia z Rokiv Blukan i Borotby Pid Trioma Okupatsiyamy Ukrainy (1921-1981) [My Life and Thoughts in Retrospect. Recollections and Reflections of a Ukrainian Dissident and Political Prisoner from the Years of Delusions and Struggle Under Three Occupations of Ukraine (1921-1981)]. Detroit: Ukrainski Visti. [in Ukrainian].

27.Sowa, A. L. (1998). Stosunki Polsko-Ukrainskie 1939-1947. Zarys problematyki [Polish-Ukrainian Relations 1939-1947. An Outline of the Issue]. Krakow: Society of History Supporters. [in Polish]

28. Viatrovych, V. (2012). Druga Polsko-Ukrainska Viyna 1942-1947 [Second Polish-Ukrainian War 1942-1947]. Kyiv: Vydavnychy Dim "Kyievo-Mohylianska Academia". [in Ukrainian].

29. Zająnczkowski, M. (2015). Ukrainskie podziemie na Lubelszyznie w okresie okupacji niemieckiej 1939-1944 [The Ukrainian Underground in Lublin Land during the German Occupation 1939-1944]. Lublin-Warzawa: ISP PAN. [in Polish].

30. Arkhiv Tsentru doslidzhen vyzvolnogo rukhu [Center for Research on the Liberation Movement Archives]. Zvit z perekhodu frontu i diy boyovykh chastyn UPA v bolshevytskomu zapilli grupy "Turiv"- "Zawichost" (vid chervnia 1944 do sichnia 1945) [Report on Fronline Crossing and Actions of the UPA Combat Units in the Bolshevist Rear, "Turiv", "Zawichost" Group (since June, 1944 till January, 1945)]. Fonds 9. Volume 30. Sheet. 1. <http://avr.org.ua/index.php/viewDoc/1078/>. (2021, September, 01). [in Ukrainian]. 